\title{
Leadership That 'Drives': Big Lessons in Leadership Can Come in Small Gestures
}

\author{
Dr. Smita Dabholkar Singh \\ Associate Professor and Chairperson Corporate Communications Committee, IMT Nagpur \\ Email: sdabholkar@imtnag.ac.in
}

Received: $20^{\text {th }}$ September 2018, Accepted: $11^{\text {th }}$ October 2018, Published: $31^{\text {st }}$ October 2018

\begin{abstract}
This article is about leadership and how leadership in small and big acts can have a profound impact on organizational behavior. It is inspired by G Sreekanth's gesture, then collector of Akola in Maharashtra, who drove his driver on his last day of work.

The purpose is to create a scope for reflections on our acts. Although the protagonist in this article, G Sreekanth is a collector and therefore in a powerful position but the author wants to drive home a point which is based on by Peter Senge's concept of leadership which compels us to think and act as if we are on a leadership position of importance. The article is based on the secondary source of information, gathered from newspaper and online news channels.
\end{abstract}

Keywords

Leadership, Emotional Intelligence and Mental Models

\section{Introduction}

John Adair, in his famous book titled, 'Effective Motivation', introduces us with two kinds of leaders. One, who are good leaders and the other who are for good. He further elaborates on the later category of leaders by stating that, "A leader for good is one who gives people an inner confidence in themselves and brings out the best in them. You may have experienced that inspirational touch yourself. Now it is your turn and your time to do the same for others. Remember, as John Buchan so memorably wrote, 'The task of the leadership is not to put greatness into others but to draw it out, for the greatness is already there.' Such leaders build into work what the early theorists called the 'intrinsic motivation".

I have been in search of such leaders always and whenever I get to see them I make it a point to document them. For they are as rare as hen's teeth. This article is about one such rare leader, G Sreekanth, then the collector of Akola in Maharashtra.

\section{Material and Method}

Material in this case is a news in the daily, The Hindustan Times, dated, November 5, 2016. News with a caption, 'Collector drives chauffeur to office as farewell gift', was an unusual one.

\section{Method}

Method used is Reflection on the leadership act and theories of leadership in particular and organizational behavior in general.

\section{The SMALL Gestures:}

Yesterday, while I was browsing the internet, I happened to come across a news article with a heading, "Collector drives chauffeur to office as farewell gift'. I was pleasantly surprised and started reading further. A Collector, from Akola, G Sreekanth showcased profound emotional intelligence. As a farewell gift, he drove down his chauffeur Digambar Thak on the last day of his office as a farewell gift ahead of the farewell ceremonies. ${ }^{1}$. What must have been the mental model of this collector? Can such leadership be taught?

It is said it takes a village to rear a child. What must have been the upbringing of this Collector like? What special did his environment do to him? What must be his set of assumptions about people, work, duty, colleagues, human beings in general and life at large? What must have been his set of values? Can we produce more of such Winning Leaders?

\footnotetext{
${ }^{1}$ https://www.deccanchronicle.com/nation/in-other-news/051116/maharashtra-ias-officer-turns-chauffeur-ondrivers-retirement-day.html
} 
Mr. Thak must have undoubtedly felt terrific about the fact that his boss was driving him to the office. Is there anything in material that he could exchange for the kind of feeling he has experienced?

"I don't have words to describe my feelings," said Thak to the reporter in an emotion-choked voice. Wasn't it a life time and life-changing experience for him? Did Mr. Sreekanth spend even a penny to create this phenomenal experience? A feeling of gratitude of such a spectacular magnitude shown by his boss must have been truly a healing moment.

\section{Reflections:}

Gestures although small and momentary in nature at times, have a profound impact on others. These gestures are behavior/ acts, acts which are dependent on one's sets of assumptions and values. Assumptions and values are both inherited and learnt.

Do students, studying professional course like medicine, engineering, architecture, pharmacy etc get an opportunity to develop an optimal understanding of managing or even understanding of the human side of their professional decisions, small or big? Do they get an exposure to an Organic Learning? ${ }^{2}$ Organizational Behavior is a compulsory subject in B-schools and Management programs in universities. In this subject most of the aspects which may affect one's behavior in organization are taught. From Emotions, Personality, Values, to topics like Power and Politics in the context of both Individual and Group is taught. But how much of it is learned by the students? Is mere knowing of the concepts, enough? How can we internalize the learnings? I am tempted to quote an excerpt from the seminal work by Daniel Goleman on emotional intelligence. In the context of those who deal with the teaching of emotional intelligence, he says, "They (let me add, 'many of them')focus on the wrong part of the brain. Emotional intelligence is born largely in the neurotransmitters of the brain's limbic system, which governs feelings, impulses, and drives. Research indicates that limbic system learns best through motivation, extended practice, and feedback. Compare this with the kind of learning that goes on in the neocortex, which governs analytical and technical ability. To enhance emotional intelligence, organizations must refocus their training to include the limbic system. They must help people break old behavioral habits and establish new ones. That not only takes much more time than conventional training programs, it also requires an individualized approach." ${ }^{3}$ Do you think we need to look at the three concepts, motivation, extended practice and feedback more deeply? Is it not a good idea to re-look at our way of teaching leadership or other behavioral management courses?

Here is another excerpt from one of my favorite books on leadership by John Adair. It resonates quite clearly with the above excerpt.

Leadership is far better learned by experience and reflection or thought, which in turn, informs or guides future action. The belief that theories or principles, imbibed from books or courses, can by themselves teach a person to lead, is a half-truth. All the academic study of leadership does is to teach one about leadership, not how to lead. It is certainly useful for people to clarify their concepts of leadership, either as a prelude or as an interlude in the practical work of leading others.

But leadership is learnt primarily through doing it, and nothing can replace that necessary cycle of experiment, trial-and-error and success and failure, followed by reflection and reading. Following this path of selfdevelopment, a person may become so effective as a leader that others will say 'He or she was born to it'. Little they know the work it took! $!^{4}$

\section{Conclusion}

I was preparing a lecture on leadership and didn't know where to begin. I want to thank Mr. Sreekanth in person someday for showing it in action. As an extension of this article I wish to come up with another one on his Mental model, his set of values and assumptions. What led to, will be worth finding, I believe.

It is said, there is nobody who cannot vastly improve his powers of leadership by a little thought and practice, This mindful and emotionally intelligent act of leadership, I guess is one of the good examples to begin the discussion on

${ }^{2}$ An organic organization is a type of informal organization originally described by British theorists Tom Burns and George Stalker. According to Burns and Stalker, an organic organization is one that is very flexible and is able to adapt well to changes. The author has coined a word based on this definition meaning learning which itself needs to be more focused on usability.

${ }^{3}$ What makes a leader, by Daniel Goleman, Best of HBR 1998

${ }^{4}$ Pg 33, Inspiring Leadership by John Adair, Viva Books Private limited. 
Leadership. How, big lessons in leadership can come in small gestures. A good thought to start, practice needs to follow.

\section{References}

1. John Adair (2009) "Effective Motvation”, Pan Books.

2. John Adair (2002) "Inspiring Leadership", Viva Books Private Limited

3. Daniel Goleman (1998) "What makes a leader," Best of HBR

4. https://www.youtube.com/watch? $\mathrm{v}=6 \mathrm{MQ} 1$ ceTrkVE 